\title{
PENGEMBANGAN PERANGKAT PEMBELAJARAN MATEMATIKA MENGGUNAKAN PENDEKATAN RECIPCORAL TEACHING UNTUK MEMFASILITASI KEMAMPUAN KOMUNIKASI MATEMATIS SISWA SMP
}

\author{
Muktiranda $^{1}$, Maimunah ${ }^{2}$, Putri Yuanita \\ 1,2,3 Universitas Riau, Pekanbaru, Riau, Indonesia \\ mukhtiranda22@yahoo.com
}

\begin{abstract}
This research is based on the low-level mathematical communication skills on junior high school students. The low mathematical communication skills on students have impacts on other mathematical abilities such as critical mathematical thinking skill, mathematical creative thinking skill, and mathematical problem solving skill. This research aims to develop mathematical learning media using valid and practical recipcoral teaching approach in facilitating mathematical communication skill for junior high school students grade $8^{\text {th }}$. This research was the ADDIE development model consisting of analysis, design, development, and implementation. Trials were conducted in two stages, expert trials, and limited trials. The test subjects in this study were students. The instruments used were validation sheets and student response questionnaires. The results show that the learning media developed have fulfilled aspects of validity and practicality. (1) validity results show that the learning device developed in the category is very valid with an average value on the syllabus 3.81, on RPP of 3.62, on LKPD 3.51, on the test instruments 3.45. (2) limited trial results show a mathematical learning media developed in the very practical category with score 3.41 .
\end{abstract}

Keywords: Mathematics Learning Media, Mathematical Communication Skill, Recipcoral Teaching Approach Abstrak

Penelitian ini dilatarbelakangi oleh rendahnya kemampuan komunikasi matematis siswa SMP. Rendahnya kemampuan komunikasi matematis siswa berdampak pada rendahnya kemampuan matematis lainnya seperti kemampuan kemampuan berpikir kritis matematis, kemampuan berpikir kreatif matematis, dan kemampuan pemecahan masalah matematis. Penelitian ini bertujuan untuk mengembangkan perangkat pembelajaran matematika menggunakan pendekatan recipcoral teaching yang valid dan praktis dalam memfasilitasi kemampuan komunikasi matematis siswa SMP kelas VII. Jenis penelitian ini adalah pengembangan model ADDIE yang terdiri atas analisis, perancangan, pengembangan, dan implementasi. Ujicoba dilaksanakan dua tahap, yaitu ujicoba ahli, dan ujicoba terbatas. Subjek ujicoba dalam penelitian ini adalah siswa. Instrumen yang digunakan terdiri atas lembar validasi dan lembar angket respon siswa. Hasil penelitian menunjukkan bahwa perangkat pembelajaran yang dikembangkan telah memenuhi aspek validitas dan praktikalitas. (1) hasil validitas menenunjukkan bahwa perangkat pembelajaran yang dikembangkan pada kategori sangat valid dengan nilai rata-rata pada silabus sebesar 3,81, pada RPP sebesar 3,62, pada LKPD sebesar 3,51, pada instumrn tes sebesar 3,45 . (2) hasil ujicoba terbatas menunjukkan perangkat pembelajaran matematika yang dikembangkan pada kategori sangat praktis sebesar 3,41.

Kata Kunci: perangkat pembelajaran matematika, kemampuan komunikasi matematis, pendekatan Recipcoral Teaching

\section{PENDAHULUAN}

Salah satu masalah penting dalam pembelajaran matematika saat ini adalah rendahnya kemampuan komunikasi matematika siswa. Kemampuan komunikasi menjadi salah satu hal yang memegang peranan penting, karena kemampuan komunikasi membantu dalam proses penyusunan pikiran dan menghubungkan gagasan dengan gagasan lain. Komunikasi memainkan peranan yang 
penting dalam membantu siswa bukan saja dalam membina konsep melainkan membina perkaitan antara ide dan bahasa abstrak dengan simbol matematika. Komunikasi membuka ruang kepada siswa untuk berbincang dan berdiskusi tentang matematika. Pengembangan komunikasi juga menjadi salah satu tujuan pembelajaran matematika. Melalui pembelajaran matematika, siswa diharapkan dapat mengkomunikasikan gagasan dengan simbol, tabel, diagram, atau media lain untuk memperjelas keadaan atau masalah.

Pentingnya kemampuan komunikasi matematis antara lain dikemukan Baroody (Hendriana, Soemarmo, 2014) dengan rasional a) matematika adalah bahasa esensial yang tidak hanya sebagai alat berpikir, menemukan rumus menyelesaikan masalah, atau menyimpulkan saja, namun matematika juga memiliki nilai yang tidak terbatas untuk menyatakan beragam idea secara jelas, teliti dan tepat; b) matematika dan belajar matematika adalah jantungnya kegiatan sosial manusia, misalnya dalam pembelajaran matematika interaksi antara guru dan siswa, antara siswa dan siswa, antara bahan pembelajaran matematika dan siswa adalah faktor -faktor penting dalam memajukan potensi siswa.

Komunikasi matematis mempunyai hubungan yang sangat kuat dengan proses-proses matematis yang lain, seperti pemecahan masalah matematis, representasi matematis, refleksi, penalaran dan pembuktian, serta koneksi, dimana komunikasi diperlukan untuk melengkapi dari setiap proses matematis yang lain. Komunikasi matematis juga merupakan alat bantu dalam transmisi pengetahuan matematika atau sebagai fondasi dalam membangun pengetahuan matematika.

Kendatipun kemampuan komunikasi matematis itu penting, namun ironisnya kemampuan komunikasi matematis siswa di Indonesia rendah. Dimyati (2013) menyatakan kemampuan komunikasi matematis siswa di Indonesia masih tergolong rendah. Sejalan dengan Hasil survei Program for International Student Assesment (PISA) tahun 2018 menunjukkan skor rata-rata Indonesia sebesar 379 dibawah rata-rata skor internasional sebesar 489 dengan peringkat 74 dari 79 negara di dunia dan juga hasil TIMSS Tahun 2015 bahwa siswa Indonesia berada pada peringkat 45 dari 50 negara.

Hafizah Delyana (2014) menyatakan salah satu penyebab kemampuan komunikasi matematis di Indonesia rendah adalah umumnya pembelajaran matematika bersifat klasikal yaitu guru masih menggunakan metode ceramah tanpa banyak melihat kemungkinan penerapan pendekatan lain yang sesuai dengan jenis materi dan bahan ajar.

Dalam menciptakan pembelajaran matematika yang dapat memfasilitasi peningkatan kemampuan komunikasi matematis, maka seorang guru perlu menggunakan perangkat pembelajaran berupa LKPD yang dapat memudahkan proses pembelajaran matematika. Sejalan dengan Anggraini (2014) menyatakan LKPD adalah salah satu perangkat pembelajaran yang dapat digunakan untuk mempermudah siswa memahami materi pembelajaran. Astari (2017) menyatakan penggunaan LKPD 
dalam pembelajaran dapat memberikan kesempatan lebih luas dalam proses kontruksi pengetahuan dalam dirinya.

Fatmawati (2016) menyatakan bahwa kualitas perangkat pembelajaran yang baik dapat dilihat dari tiga aspek yaitu: validitas, kepraktisan, dan keefektifan. Dalam penelitian ini perangkat pembelajaran matematika yang akan dikembangkan memenuhi kriteria valid dan praktis. Rochmad (2012) mengatakan perangkat pembelajaran yang dikembangkan dikatakan valid jika perangkat tersebut berdasarkan teori yang memadai dan semua komponen perangkat pembelajaran yang digunakan berhubungan secara konsisten. Titik Yuniarti (2014) juga menyatakan perangkat pembelajaran dinyatakan valid jika perangkat yang dikembangkan didasarkan pada rasional teoritik yang kuat dan terdapat konsistensi internal.

Kriteria penilaian validitas perangkat pembelajaran pada penelitian ini mengacu pada pendapat Sa'adun Akbar (2013). Kriteria penilaian validitas perangkat pembelajaran dalam penelitian ini dapat dilihat pada Tabel 1 berikut.

\section{Tabel 1.}

Kriteria Penilaian Validitas

\begin{tabular}{|c|c|}
\hline Interval & Tingkat Validitas \\
\hline $3,41-4,00$ & Sangat valid \\
\hline $2,81-3,40$ & Valid \\
\hline $2,01-2,80$ & Kurang valid \\
\hline $1,00-2,00$ & Tidak valid \\
\hline
\end{tabular}

Titik Yuniarti (2014) juga menyatakan perangkat pembelajaran dikatakan praktis jika memenuhi aspek kepraktisannya yaitu bahwa perangkat pembelajaran dapat diterapkan. Jadi perangkat pembelajaran dikatakan praktis apabila perangkat tersebut memenuhi aspek kepraktisannya yaitu dapat digunakan dengan mudah oleh guru dan peserta didik serta tingkat keterlaksanaannya dalam kategori baik.

Kriteria penilaian praktikalitas perangkat pembelajaran pada penelitian ini mengacu pada pendapat Sa'adun Akbar (2013). Kriteria penilaian praktikalitas perangkat pembelajaran dalam penelitian ini dapat dilihat pada Tabel 2.berikut.

Tabel 2.

Kriteria Penilaian praktikalitas

\begin{tabular}{cc}
\hline Interval & Tingkat Praktikalitas \\
\hline $3,41-4,00$ & Sangat Praktis \\
\hline $2,81-3,40$ & Praktis \\
\hline $2,01-2,80$ & Kurang Praktis \\
\hline $1,00-2,00$ & Tidak Praktis \\
\hline
\end{tabular}

LKPD yang baik harus disesuaikan dengan model atau pendekatan pembelajaran. Penggunaan model atau pendekatan pembelajaran yang baik dapat memfasilitasi kegiatan pembelajaran yang aktif. 
Dalam proses pembelajaran LKPD. Oleh karena itu, diperlukan suatu pendekatan pembelajaran yang tepat, menarik dan harus efektif sehingga siswa dapat aktif dalam keadaan kegiatan pembelajaran dan dapat menghasilkan apa yang harus dikuasai siswa setelah proses pembelajaran. Salah satu pendekatan pembelajaran yang bisa diterapkan adalah pendekatan Reciprocal Teaching (pengajaran terbalik). Melalui pendekatan Reciprocal Teaching ini, siswa diharapkan belajar melalui "mengalami" bukan "menghafal".

Menurut Risnawati (2008), pengajaran terbalik (Reciprocal Teaching) adalah suatu prosedur pembelajaran yang dirancang untuk mengajari siswa empat strategi pemahaman mandiri, yaitu merangkum, membuat soal yang berkaitan dengan materi, menjelaskan dan memprediksi. Menurut Ann Brown dalam Amin Suyitno (2004), pada pembelajaran ini, para siswa diajarkan empat strategi pemahaman mandiri yang spesifik, yaitu: a) Siswa mempelajari materi yang diajarkan guru secara mandiri, selanjutnya merangkum/meringkas materi tersebut; b) Siswa membuat pertanyaan ini diharapkan siswa mampu mengungkapkan penguasaan materi yang bersangkutan; c) Siswa mampu menjelaskan kembali isi materi tersebut kepada pihak lain; d) Siswa dapat memprediksi kemungkinan pengembangan materi yang dipelajari saat itu.

Siti Rokiah (2020) menjelaskan pendekatan pembelajaran reciprocal teaching adalah model pembelajaran kooperatif dengan metode diskusi dan memberikan kesempatan proses berpikir siswa dengan saling bertukar pengalaman belajar yang menerapkan empat strategi pemahaman mandiri, yaitu menyimpulkan bahan ajar, menyusun pertanyaan dan menyelesaikannya, menjelaskan kembali pengetahuan yang telah di perolehnya, kemudian memprediksi pertanyaan selanjutnya dari persoalan yang di sodorkan kepada siswa

Kegiatan merangkum, membuat soal, menjelaskan dan memprediksi akan menuntut kesiapan siswa menerima pelajaran matematika, memusatkan perhatian, meningkatkan keaktifan dan ketekunan siswa dalam belajar,merangsang keingintahuan siswa sehingga kebosanan dalam belajar akan hilang dan siswa akan merasa senang dan puas dengan materi pelajaran matematika yang diajarkan.

Dari pemaparan diatas dapat disimpulkan bahwa LKPD dengan pendekatan pembelajaran recipcoral teaching dapat membantu mengembangkan kemampuan komunikasi matematis siswa. Sehingga dalam penelitian ini dikaji tentang "Pengembangan perangkat pembelajaran matematika menggunakan pendekatan recipcoral teaching untuk memfasilitasi kemampuan komunikasi matematis ". Rumusan masalah dalam penelitian ini adalah Bagaimana perangkat pembelajaran matematika menggunakan pendekatan reciprocal teaching untuk memfasilitasi kemampuan komunikasi matematis siswa SMP memenuhi kriteria valid dan praktis. Tujuan penelitian adalah untuk menghasilkan perangkat pembelajaran matematika menggunakan pendekatan reciprocal teaching untuk memfasilitasi kemampuan komunikasi matematis siswa SMP yang valid dan praktis. 


\section{METODE}

Penelitian ini merupakan penelitian pengembangan. Produk dari penelitian pengembangan ini adalah perangkat pembelajaran matematika menggunakan pendekatan recipcoral teaching untuk peserta didik SMP kelas VII. Perangkat yang dikembangkan yaitu silabus, rencana pelaksanaan pembelajaran (RPP) dan lembar kegiatan Peserta Didik (LKPD), dan Instrumen tes kemampuan komunikasi matematis siswa. model pengembangan yang digunakan dalam penelitian ini adalah model ADDIE yang dikembangkan oleh Sugiyono. Adapun langkah penelitian pengembangan ADDIE dalam penelitian ini jika disajikan dalam bentuk bagan adalah sebagai berikut:

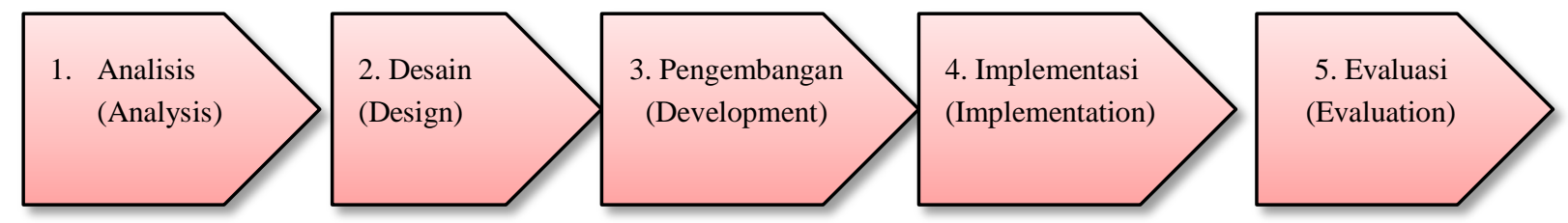

Gambar 1. Langkah-Langkah Model Pengembangan ADDIE (Sugiyono, 2015)

Penelitian dilaksanakan pada bulan September 2020 di SMP N 1 Parangtapah Rokan Hulu. Subjek uji coba dalam penelitian ini adalah siswa kelas VII. Subjek uji coba terbatas dipilih secara acak dari kelas VIII sebanyak 10 siswa.

Prosedur pengembangan dalam peneltian ini mengacu pada lima tahapan yaitu: analisis, perancangan, pengembangan, implementasi, dan evaluasi. Pada tahap analisis dilakukan beberapa kegiatan analisis sebagai acuan perancangan produk awal, yaitu: 1) analisis kebutuhan, 2) analisis karakteristik peserta didik, 3) analisis materi pembelajaran.

Pada tahapan rancangan dilakukan beberapa kegiatan yaitu peneliti merancang perangkat pembelajaran berupa silabus, RPP, LKPD dan instrumen tes. Pada tahap pengembangan peneliti melakukan dua kegiatan yaitu mengembangkan perangkat pembelajaran dan melakukan uji coba ahli.

Pada tahap Implementasi dilakukan satu tahapan uji coba yaitu uji coba terbatas. Tahap terakhir dilakukan kegiatan Evaluasi. Evaluasi perangkat pembelajaran dilakukan sejak tahap pengembangan yaitu evaluasi validitas perangkat pembelajaran oleh para ahli, dan evaluasi pada saat ujicoba terbatas.

Teknik pengumpulan data dalam penelitian ini yaitu teknik non tes. Teknik non tes dilakukan melalui pemberian lembar validasi, dan lembar angket respon siswa. Instrumen yang digunakan dalam penelitian ini yaitu lembar validasi, dan lembar penilaian siswa. Teknik analisis data dalam penelitian ini adalah analisis validitas dan analisis praktikalitas

\section{HASIL}

Dalam mengembangkan perangkat pembelajaran, pemilihan format dilakukan. Pilihan format disesuaikan dengan langkah-langkah pendekatan recipcoral teaching. Kemudian format masing- 
masing perangkat dikembangkan. Setelah selesai, perangkat pembelajaran divalidasi oleh validator dan dilanjutkan dengan uji coba. Berikut ini adalah gambar sampul LKPD yang direvisi (Gambar 1).

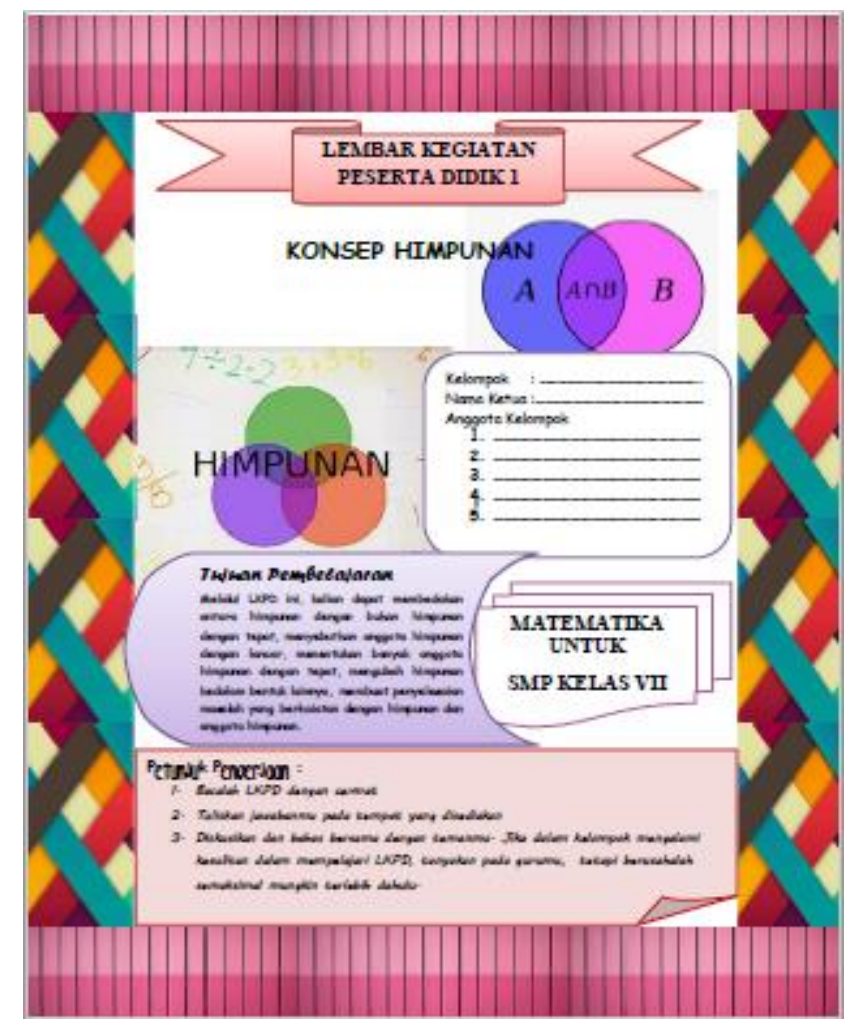

Gambar 2. Gambar Sampul LKPD yang Direvisi

\section{Hasil Validasi}

Produk awal perangkat pembelajaran yang dikembangkan terlebih dahulu di validasi oleh para ahli yang bertujuan untuk melihat kualitas produk yang ditinjau dari isi. Validasi perangkat pembelajaran dilakukan oleh tiga orang ahli dengan memberi penilaian terhadap silabus, RPP, LKPD, dan instrumen tes

Penilaian validator terhadap silabus meliputi aspek identitas, KI dan KD, Rumusan IPK, materi pembelajaran, kegiatan pembelajaran, penilaian hasil belajar, alokasi waktu, dan sumber belajar. Adapun hasil analisis data validasi oleh validator terhadap silabus seperti pada Tabel 3

\section{Tabel 3.}

Hasil validasi terhadap silabus

\begin{tabular}{|c|l|c|c|}
\hline No & Indikator & Rata-rata & Kriteria \\
\hline 1 & Identitas Silabus & 3,50 & Sangat Valid \\
\hline 2 & Kompetensi inti dan KD & 3,89 & Sangat Valid \\
\hline 3 & Rumusan Indikator Pencapaian Kompetensi & 3,33 & Valid \\
\hline 4 & Materi Pembelajaran & 3,56 & Sangat Valid \\
\hline 5 & Kegiatan Pembelajaran & 3,67 & Sangat Valid \\
\hline 6 & Penilaian hasil belajar & 3,33 & Valid \\
\hline 7 & Alokasi waktu & 3,50 & Sangat Valid \\
\hline 8 & Sumber Belajar & 3,17 & Valid \\
\hline \multicolumn{2}{r|}{ Rata-rata } & 3,49 & Sangat Valid \\
\hline
\end{tabular}

Sumber: Data olahan peneliti (2020) 
Hasil penilaian validator terhadap silabus di atas menunjukkan bahwa rata-rata memperoleh nilai 3,49 berada dalam kategori sangat valid artinya silabus yang dikembangkan layak untuk di ujicoba.

Penilaian validator terhadap RPP meliputi aspek identitas, KI dan KD, Rumusan IPK, materi pembelajaran, kegiatan pembelajaran, penilaian hasil belajar, alokasi waktu, sumber belajar, dan kebahasaan. Adapun hasil analisis data validasi oleh validator terhadap RPP dapat dilihat pada Tabel 4.

\section{Tabel 4.}

Hasil Validasi RPP

\begin{tabular}{|c|l|c|c|}
\hline No & \multicolumn{1}{|c|}{ Aspek yang dinilai } & Rata-rata & Kategori \\
\hline 1 & Identitas & 4,00 & Sangat valid \\
\hline 2 & KI dan KD & 3,83 & Sangat valid \\
\hline 3 & Rumusan IPK & 3,51 & Sangat valid \\
\hline 4 & Tujuan pembelajaran & 3,69 & Sangat valid \\
\hline 5 & Materi pembelajaran & 3,62 & Sangat valid \\
\hline 6 & Kegiatan pembelajaran & 3,69 & Sangat valid \\
\hline 7 & Pemilihan sumber belajar & 3,41 & Sangat Valid \\
\hline 8 & Pencapaian hasil belajar & 3,26 & Valid \\
\hline 9 & Alokasi waktu & 3,57 & Sangat valid \\
\hline 10 & Kebahasaan & 3,53 & Sangat valid \\
\hline & Rata-rata & 3,61 & Sangat valid \\
\hline
\end{tabular}

Sumber: Data olahan peneliti (2020)

Hasil validasi terhadap RPP secara keseluruhan memperoleh nilai rata-rata 3,61 berada dalam kategori sangat valid, artinya RPP yang dikembangkan menggunakan pendekatan recipcoral teaching untuk memfasilitasi kemampuan komunikasi matematis layak untuk di uji coba.

Penilaian validator terhadap LKPD meliputi aspek isi, kelayakan bahasa, kelayakan kegiatan siswa, kelayakan waktu, kemenarikan, dan komponen. Adapun hasil analisis data validasi oleh validator terhadap LKPD dapat dilihat pada Tabel 5.

\section{Tabel 5.}

\section{Hasil Validasi LKPD}

\begin{tabular}{|c|l|c|c|}
\hline No & Aspek yang dinilai & Rata-Rata & Keterangan \\
\hline 1 & Isi & 3,42 & Sangat valid \\
\hline 2 & Kelayakan bahasa & 3,64 & Sangat valid \\
\hline 3 & kelayakan kegiatan Siswa & 3,51 & Sangat valid \\
\hline 4 & Kelayakan Waktu & 3,00 & Valid \\
\hline 5 & Kemenarikan & 3,48 & Sangat valid \\
\hline 6 & Komponen & 3,70 & Sangat valid \\
\hline & Rata-rata & 3,45 & Sangat valid \\
\hline
\end{tabular}

Sumber: Data olahan peneliti (2020)

Berdasarkan Tabel 3 Hasil validasi terhadap LKPD, secara keseluruhan memperoleh nilai ratarata 3,45 berada dalam kategori sangat valid, artinya LKPD menggunakan pendekatan recipcoral teaching untuk memfasilitasi kemampuan komunikasi matematis yang dikembangkan layak untuk di 
uji coba.

Penilaian validator terhadap instrumen tes yang mengukur kemampuan komunikasi matematis meliputi aspek Materi, kontstruksi, dan bahasa. Adapun hasil validasi instrumen tes dari validator dapat dilihat pada Tabel 6.

\section{Tabel 6.}

Hasil Validasi terhadap Intrumen tes

\begin{tabular}{|c|c|c|c|c|l|}
\hline \multirow{2}{*}{ No Soal } & \multicolumn{4}{|c|}{ Aspek yang dinilai } & \multirow{2}{*}{ Keterangan } \\
\cline { 2 - 5 } & Materi & Kontruksi & Bahasa & Rata-rata & \\
\hline 1 & 3,73 & 3,40 & 3,67 & 3,60 & Sangat valid \\
\hline 2 & 3,80 & 3,53 & 4,00 & 3,78 & Sangat valid \\
\hline 3 & 3,67 & 3,73 & 3,75 & 3,72 & Sangat valid \\
\hline 4 & 3,60 & 3,47 & 3,50 & 3,52 & Sangat valid \\
\hline 5 & 3,53 & 3,67 & 3,42 & 3,54 & Sangat valid \\
\hline Rata-rata & 3,67 & 3,56 & 3,67 & 3,63 & Sangat valid \\
\hline Keterangan & Sangat valid & Sangat valid & Sangat valid & Sangat valid & \\
\hline
\end{tabular}

Sumber: data olahan peneliti (2020)

Berdasarkan Tabel 4. Hasil validasi terhadap instrumen tes yang mengukur kemampuan komunikasi matematis. Secara keseluruhan memperoleh nilai rata-rata 3,63 berada dalam kategori sangat valid, artinya instrumen tes yang mengukur kemampuan komunikasi matematis yang dikembangkan layak untuk di uji coba.

\section{Data Hasil Ujicoba Terbatas}

Setelah melakukan validasi, peneliti menghitung dan menganalisis hasil validasi perangkat pembelajaran berupa silabus, RPP, LKPD, dan instrumen tes yang mengukur kemampuan komunikasi matematis. Peneliti juga memperbaiki perangkat pembelajaran yang dikembangkan sesuai dengan saran dari validator. Produk yang telah divalidasi dan direvisi selanjutnya dilakukan uji coba terbatas untuk mengetahui keterbacaan dari perangkat. Uji coba ini dilakukan terhadap 10 orang peserta didik yang mempunyai kemampuan heterogen yang diambil dari peserta didik kelas VIII SMP N 1 Pagarantapah Rokan Hulu. Hasil uji coba terbatas terhadap LKPD yang dikembangkan dapat dilihat pada tabel 7 berikut.

Tabel 7.

Hasil Angket Peserta Didik terhadap Keterbacaan LKPD

\begin{tabular}{|l|c|c|c|c|c|c|}
\hline Aspek & LKPD1 & LKPD2 & LKPD3 & LKPD4 & LKPD5 & Rata-Rata \\
\hline Kelayakan isi & 3,35 & 3,32 & 3,25 & 3,42 & 3.42 & 3,34 \\
\hline Kelayakan bahasa & 3,47 & 3,25 & 3,50 & 3,63 & 3,55 & 3,48 \\
\hline Kelayakan kegiatan & 3,49 & 3,34 & 3,29 & 3,46 & 3,42 & 3,40 \\
\hline Waktu & 3,30 & 3,20 & 3,30 & 3,00 & 3,20 & 3,20 \\
\hline Kemenarikan & 3,35 & 3,34 & 3,35 & 3,51 & 3,46 & 3,40 \\
\hline Rata-rata per LKPD & 3,39 & 3,29 & 3,34 & 3,40 & 3,41 & 3,36 \\
\hline Rata-rata Total & \multicolumn{7}{|l|}{3,36} \\
\hline
\end{tabular}


Sumber: data olahan peneliti (2020)

Berdasarkan Tabel 7. Hasil angket respon siswa terhadap keterbacaan LKPD dan disesuaikan dengan kriteria penilaian praktikalitas perangkat pembelajaran pada table 2, maka pada LKPD 1 memperoleh nilai 3,39 berada dalam kriteria praktis, LKPD 2 memperoleh nilai 3,29 berada dalam kriteria praktis, LKPD 3 memperoleh nilai 3,34 berada dalam kriteria praktis, LKPD 4 memperoleh nilai 3,40 berada dalam kriteria praktis, LKPD 5 memperoleh nilai 3,41 berada dalam kriteria sangat praktis praktis, dan secara keseluruhan memperoleh nilai rata-rata 3,36 berada dalam kategori praktis, artinya perangkat pembelajaran yang dikembangkan " praktis " digunakan oleh peserta didik.

\section{KESIMPULAN}

Berdasarkan hasil penelitian dan pengembangan yang telah diuraikan diperoleh beberapa simpulan. (1) Produk perangkat pembelajaran matematika menggunakan pendektan recipcoral teaching untuk memfasilitasi kemampuan komunikasi matematis siswa SMP kelas VII semester ganjil memiliki empat strategi pemahaman mandiri, yaitu merangkum, membuat soal yang berkaitan dengan materi, menjelaskan dan memprediksi. (2) Produk akhir perangkat pembelajaran matematika menggunakan pendektan recipcoral teaching untuk memfasilitasi kemampuan komunikasi matematis siswa SMP berdasarkan penilaian dosen ahli silabus memperoleh nilai rata-rata 3,49 dengan kriteria sangat valid, RPP memperoleh nilai rata-rata nilai 3,61 dengan kriteria sangat valid, LKPD memperoleh nilai rata-rata 3,45 dengan kriteria sangat valid, dan instrument tes memperoleh nilai rata-rata 3,63 dengan kriteria sangat valid. Secara keseluruhan perangkat pembelajaran matematika memenuhi kriteria sangat valid. (3) Produk akhir perangkat pembelajaran matematika menggunakan pendektan recipcoral teaching untuk memfasilitasi kemampuan komunikasi matematis siswa SMP berdasarkan penilaian siswa memenuhi kriteria praktis.

\section{DAFTAR PUSTAKA}

Anggraini, W., Anwar, Y., \& Madang, K. (2016). Pengembangan Lembar Kerja Peserta Didik (LKPD) Berbasis Learning Cycle 7E Materi Sistem Sirkulasi Pada Manusia Untuk Kelas XI SMA. Jurnal Pembelajaran Biologi, 3(1), 49-57.

Astari, T. (2017). Pengembangan Lembar Kerja Siswa (LKS) berbasis Pendekatan Realistik untuk Meningkatkan Hasil Belajar Siswa SD Kelas IV. Jurnal Pelangi, 9(2).

Delyana, H. (2014). Peningkatan Kemampuan Komunikasi Matematis dan Disposisi Matematis Siswa Smp Melalui Penerapan Strategi The Firing Line dalam Pembelajaran Matematika (Doctoral dissertation, Universitas Pendidikan Indonesia). 
Dimyati, A. (2020). Analisis Kemampuan Komunikasi Matematis Siswa Melalui Model SSCS Problem Solving dengan Metode Hypnoteaching. Supermat (Jurnal Pendidikan Matematika), 4(1), 1-15.

Fatmawati, A. (2016). Pengembangan Perangkat Pembelajaran Konsep Pencemaran Lingkungan Menggunakan Model Pembelajaran Berdasarkan Masalah Untuk SMA Kelas X. Edu Sains: Jurnal Pendidikan Sains dan Matematika, 4(2).

Hendriana, H., \& Soemarmo, U. (2014). Penilaian Pembelajaran Matematika. Bandung: Refika Aditama.

Risnawati, S. P. M. (2008). Pekanbaru.

Rochmad, R. (2012). Desain Model Pengembangan Perangkat Pembelajaran Matematika. Kreano, Jurnal Matematika Kreatif-Inovatif, 3(1), 59-72.

Rokiah, S., Elindra, R., \& Lubis, R. (2020). Efektivitas Penggunaan Model Pembelajaran Reciprocal Teaching Terhadap Kemampuan Pemecahan Masalah Matematis Siswa Di MTs. ALMukhtariyah Sungai Dua Portibi. JURNAL MathEdu (Mathematic Education Journal), 3(2), $35-42$.

Sa'dun Akbar. 2013, Instrumen Perangkat Pembelajaran, PT. Remaja Rosdakarya, Bandung.

Sugiyono, P. D. (2010). Metode penelitian pendidikan. Pendekatan Kuantitatif.

Suyitno, A. (2004). Dasar-dasar dan proses pembelajaran matematika I. Semarang: Unnes.

Yuniarti, T., Riyadi, R., \& Subanti, S. (2014). Pengembangan Perangkat Pembelajaran Berbasis Masalah (Problem Based Learning) Dengan Pendekatan Ilmiah (Scientific Approach) pada Materi Segitiga Kelas VII SMP Se-Kabupaten Karanganyar Tahun Pelajaran 2013/2014. Jurnal Pembelajaran Matematika, 2(9). 